\title{
ECUADOR AFTER THE COMMODITIES BOOM: A RENTIER SOCIETY'S LABYRINTH
}

\section{Ecuador después del boom de las materias primas: el laberinto de una sociedad rentista}

\begin{abstract}
Pedro Alarcón
Facultad Latinoamericana de Ciencias Sociales (FLACSO),

Ecuador.

Stefan Peters

(Justus-Liebig-Universität Giessen, Instituto Colombo-Alemán

para la Paz - CAPAZ)

Informações do artigo

Recebido em 30/04/2020

Aceito em 07/08/2020

doi>: https://doi.org/10.25247/2447-861X.2020.n250.p251-278
\end{abstract}

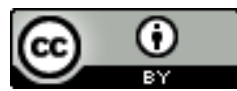

Esta obra está licenciada com uma Licença Creative Commons Atribuição 4.0 Internacional.

Como ser citado (modelo ABNT)

ALARCÓN, Pedro; PETERS, Stefan. Ecuador after the commodities boom: a rentier society's labyrinth. Cadernos do CEAS: Revista Crítica de Humanidades. Salvador, v. 45 , n. 250 , p. 251-278, set./dez. 2020. DOI: https://doi.org/10.25247/2447861X.2020.n250.p251-278

\begin{abstract}
After failing to renegotiate debt conditions with China, Lenín Moreno's government reverted to traditional international financial measures in a further attempt to cover the fiscal deficit left by the dramatic drop in oil prices of 2014. In order to meet targets agreed with lenders, Moreno scrapped subsidies on transportation fuels by the beginning of October 2019. However, amid nationwide protests, Moreno repealed the measure after nearly two weeks. Interpretations of the protests have been manifold; this paper presents a further reading based on rentier theory, and argues that a significant source of opposition to the elimination of subsidies is to be found in peoples' claim on their portion of oil rent, the expression of a quasi-naturalized right derived from living in a natural resources-rich country.

Keywords: Latin America. Neo-extractivism. Natural resources rent. Peripheral state. Development. Development theories.

Resumen

Luego de fracasar en la renegociación de las condiciones de la deuda con China, el gobierno de Lenín Moreno tocó a la puerta de las instituciones de financiamiento tradicionales para tratar de cubrir el déficit fiscal generado por la dramática caída de los precios del petróleo del 2014. Para poder cumplir con los acreedores internacionales, Moreno eliminó los subsidios a los combustibles utilizados en el sector transporte a inicios de octubre de 2019. Sin embargo, en medio de protestas generalizadas, el presidente se vio obligado a revertir la medida luego de dos semanas. La literatura académica ha provisto de una serie de interpretaciones de las protestas; este artículo presenta una lectura inédita que se fundamenta en la teoría rentista y argumenta que una fuente importante de oposición a la eliminación de los subsidios se encuentra en el reclamo de los ciudadanos por su porción de renta petrolera, la expresión de un derecho cuasi naturalizado que se deriva de vivir en un país rico en recursos naturales.

Palabras clave: América Latina. Neo-extractivismo. Renta. Estado periférico. Teorías del desarrollo.
\end{abstract}

\section{Introduction: In the Mid of the 21st Century Crisis}

The year 2020 is already a watershed. The global economy is in the deepest crisis since the Great Depression (1929) (GOPINATH, 2020). However, the coronavirus does not only checkmate the economy. More severely, it deepens many social problems and unveils clear 
signals of a humanitarian catastrophe. Those who will especially suffer from the social consequences of the economic lockdown and precarious health systems are the world's havenots living in the Global South.

No doubt, the coronavirus is an unexpected driver of the economic, social and political crisis. Though, somehow the virus did merely exacerbate the already existing problems in vast parts of the Global South. This is especially true for the natural resource-dependent countries (PETERS, 2020). The end of the bonanza in 2014 cast a shadow over the optimism that reigned during a decade. Natural resource-dependent countries all over the world suffered in different degrees from the commodity price downturn on the world market. After all, even before the start of the pandemic in 2019 different countries like Algeria, Iran, Sudan and several Latin American countries illustrate that the time before the coronavirus was far from idyllic and various authors point out that once the current crisis is overwhelmed, a back to normal would equal preparing the next crisis.

Yet, in order to find answers to the underlying problems one first needs to analyze the processes leading to crisis. This is actually the objective of the present article. It offers an indepth analysis of the political economy and sociology of natural resource-dependent countries focusing on the paradigmatic case of Ecuador. In April 2020, the country infamously filled the headlines of international newspapers with stories of people literally dying in the streets from COVID-19 in its biggest city Guayaquil (LEÓN; KURMANAEV 2020; ESPAÑA, 2020).

The coronavirus made a bad situation worse. It hit Ecuador in the mid of a severe crisis that started with the end of the last "commodities super-cycle" in 2014 (ERTEN; OCAMPO 2013; CANUTO, 2014). An economic crisis with a recession, growing public account deficits and increasing foreign debt led to a social crisis including increasing poverty rates. In October 2019 after the government's announcement of a cut on fuel subsidies in order to fulfil International Monetary Fund's (IMF) credit measures, already existing generalized public displeasure ended in political uproar. Social movements led by indigenous organizations took the streets of Quito and could not even be stopped by repression or the declaration of a state of emergency. In the end, street pressure forced President Lenín Moreno to negotiate with indigenous movements and to bury the fuel price hike (PONCE et al. 2020). This could ameliorate the political crisis, showed changing power relations, but the underlying economic and social crises remain unsolved. 
We argue that the ongoing crisis is the repeated story of failed attempts of resourceled modernization, while political turmoil was the consequence of questioning the foundations of the rentier bargain and therefore trying to alter state-society relations. We analyze both issues in this paper by taking advantage of insights from political economy and sociology of natural resource-dependent countries, more specifically from critical rentier theory. Based on these concepts, our contribution aims to present a theoretical discussion founded on empirical evidence of the paradigmatic case of Ecuador, which is delivered by an approach to the milestones of half-century economic history including the events of October 2019. In the argumentative core, structural aspects of the Ecuadorian social formation are scrutinized within the framework of rentier theory, whereas relevant aspects of the Ecuadorian economy are examined through the lens of the resource curse thesis. The end of the twenty-first century commodities boom (2003-2014) is a point of entry to reexamine key premises of rentier theory, and thereby to delve into the region's critical juncture.

This paper draws on theoretical insights based on empirical work on several oildependent countries and empirical work in Ecuador conducted by the authors. It is structured as follows. First, it locates the debate on natural resources and development in a rentier theory perspective and presents three crucial issues of the state in rentier societies: a) the initial bargaining on rent appropriation; b) strategies of economic diversification by an extractivist developmental state; and c) rent distribution and state-society relations. Afterwards the article contextualizes the debate on natural resource-based development models in Latin America and briefly discusses the concept of neo-extractivism. Then the article delves into the case study and presents an analysis of the role of the state in either Ecuadorian oil booms (1972-1980 and 2003-2014) and in the recent crisis based on the aforementioned categories of analysis. The article closes with conclusions on the Ecuadorian case and points out areas that require further research.

\section{Natural Resource-Based Development Models and Rentier Theory}

According to the World Trade Organization (WTO) (2014, p. 10), 81 out of 192 countries of the world are 'resource-driven', whereas the United Nations Conference on Trade and Development (UNCTAD) (2019, p. 17) - based on a different definitions - classifies 
102 countries as 'resource dependent'. Most of these countries are in the Global South and the majority of them can be classified as rentier societies. In classical Political Economy, rent refers to the kind of surplus generated by mere property over natural resources as opposed to the income obtained from the exploitation of labor/capital (profit) or the selling of labor (wages). Hence, theoretically, rent is put straightaway at the rentier's disposal. Since it appears delinked from the concept of labor and it is not gained on a basis of competition, the nature of rent has been assigned a negative load in academic literature. Whereas Mayer (1999, p. 4) argued that it corresponds to any revenue "in excess of production costs and a normal return on capital", Saad-Filho and Weeks (2013, p. 4) identified rent as an "unearned, temporary, and undeserved" revenue ${ }^{1}$. The origin of rent as well as its destiny have also been put under scrutiny. Inherent to its nature is the way in which rent might be collected, either from "power-based means" (WILCOCK et al. 2016, p. 12), or from privilege-based means. Precisely due to this origin, the use of rent is not subject to economic control mechanisms but depends on political or social considerations (ELSENHANS, 1986, p. 32). Rentier Societies are social formations on local, regional or national level that have depended at least since several decades on rent income. In these social formations, rent permeates the economy, politics and social relations (PETERS, 2019).

Despite the international transfer of rent might have contributed to economic growth in certain countries (particularly during natural resources boom periods), as stipulated in classic approaches from modernization theory (LEWIS, 1955; ROSTOW, 1960), in Latin American development thinking rent has been regarded as a main hindrance to the development process. Natural resources rent has been blamed for the perpetuation of the outward-oriented development model as it enabled natural resources-rich countries to increase their import capacity of manufactured goods from the Global North through the mere intensification of natural resources extraction, i.e. without the need of promoting other more productive sectors of the domestic economy or investing in research and development (BAPTISTA, 2010, p. 153; WAINER; BELLONI, 2016).

1 Oil windfall revenues decisively contributed to cement the negative idea of rent. Ross $(2013,27)$ argued that oil revenues are marked by their exceptionally large size, unusual source, lack of stability, and secrecy. In the same vein, Saad-Filho and Weeks (2013, p. 19), defined windfalls as "economic gains realized without sacrifice, or without the expenditure of resources"; the authors emphasized that the term windfall is used to imply that the gain is temporary, and suggested that it results from "luck rather than effort". 
In rentier societies, the question who manages to appropriate what share of natural resource rent is crucial. Especially regarding subsoil point resources, and above all oil and gas, during the twentieth century the state increased its role in the natural resource business both by a) nationalizing reserves and/or creating state-owned companies, and b) by increasing royalties and taxes, mainly through the renegotiation of contracts with companies. Especially in boom phases, the state has a privileged position that allows it to siphon off considerable amounts of rents that go "from foreign sources directly to government coffers" (AHMADOV, 2014, p. 1240). As a consequence of this "initial bargaining" (KARL, 1999, p. 34) with private capital (foreign and/or domestic) the state becomes first an "effective landlord", i.e. a state that exerts control over the rents generated by the natural resources of its national (sub)soil (CORONIL, 1997, p. 65). This "initial bargaining", which sometimes reminds rather of an open struggle for the control of natural resources rent ${ }^{2}$ during boom periods, is central to understand the establishment of the rentier state as a political regime3.

Secondly, according to Karl (1999, p. 34), the initial bargaining undertaken by the state left a legacy of "overly-centralized political power". In a context of a weak or even absent fiscal contract with society ${ }^{4}$, the state might reduce or even erase its dependence on the democratic participation of its citizens for legitimacy (ROSS, 2001; HERB, 2005). Massive natural resource rent influx provides the rentier state with substantial financial leeway and converts it in the principal development agent. Several oversized or even megalomaniac development projects give account of the rentier states' yearning for quick modernization and international reputation. However, it is not all a tale of white elephants (ROBINSON; TORVIK, 2005). Already in the early years of the oil age, discussions on economic diversification came up. In Venezuela, Arturo Uslar Pietri in 1936 famously called for 'sowing the oil' (USLAR PIETRI, 1936) in order to harvest development.

\footnotetext{
2 The case of oil is paradigmatic; national states grasped at diverse strategies in order to capture a larger portion of rent than that left by the payment of royalties (i.e. the share of surplus payed by private oil companies for land concessions). National states switched from concession systems to contractual systems in order to obtain a share in the profits of private companies, instead of solely royalty payments. Besides, national states enforced diverse schemes of taxation. Though, the most effective way to capture a larger portion of oil rent proved to be the establishment of national oil companies.

3 Main characteristics of rentier states have to do with its financial dependence on international rent income rather than on the domestic economy, and the fact that domestic rent distribution mediates the relations between the state and society (BEBLAWI; LUCIANI, 1987).

4 The rentier state relies financially on international rent income rather than on the national economy.
} 
There is indeed a broad consensus in development studies on the benefits of economic diversification (SACHS; WARNER, 1995; HUMPHREYS et al. 2007; UNCTAD 2016). In a similar vein, especially during the second half of the twentieth century, quite all natural resource-dependent countries committed themselves to what Larrain $(1989,87)$ called "the industrial society paradigm" by developing and applying strategies for economic diversification. These meant generally planned mobilization of public resources to sponsor industrial development (through the enforcement of preferential credits, the reduction of taxes, the regulation of import tariffs, and even the establishment of public enterprises or other strategies such as boosted investments in tertiary education). Although several states managed to increase industrial production, the overall outcomes were largely disappointing. The manufacturing sector generally remained highly dependent on state transfers and could not attain the expected gains in productivity and international competition (PURROY, 1997). However, during the last commodities boom, resource-dependent countries all over the world claimed for economic diversification, and (again) aimed to expand their non-resource economic sectors (PURROY, 1997; HVIDT, 2013; OVADIA, 2016).

Thirdly, due to politics of rent distribution the state acts as a powerful "arbiter" (CONAGHAN, 1988, p. 48). Rent pouring from the state coffers might reach the whole society, although the social groups get quite dissimilar shares of rent. Generally speaking, state-led rent allocation occurs through diverse mechanisms and (re-) produces social inequalities. The distribution of natural resource rents typically includes activities that mainly bring profits for business, upper and middle classes like access to lucrative and sometimes inflated state contracts and business opportunities for local investors, subsidized credits, low taxation, overvaluation of the currency, subsidies on transportation fuels, and the creation of professional employment opportunities in the public sector. On the other hand, lower classes benefit mostly from subsidies on basic goods, public transportation, creation of low-skill government jobs and public spending in social policy programs and infrastructure.

The enforcement of some of these measures might fall under the wide scope of clientelistic practices, which offer certain social groups privileged access to state services or benefits in exchange of political loyalty to a certain political group (BECKER, 2008, p. 19). Anyway, due to rent distribution the state holds a powerful tool to mold social structures and to produce winners and losers (PETERS, 2019). However, contrary to a widespread assumption from rentier theory, rent distribution does not necessarily provide the state with 
a high degree of autonomy. Rather, long-term rent distribution creates quasi-naturalized rights and expectancies by society. These might differ in scope between social groups, but in case of governments questioning them, society will defend and reclaim these quasinaturalized rights and expectancies loudly (BAUTISTA URBANEJA, 2013; HERB, 2014; PETERS, 2019).

\section{Latin American Extractivism}

Of course, for Latin America natural resource dependency is not new. Quite the contrary, one might claim that Latin American history is a history of extractivism (GALEANO, 2014). Yet, during the recent commodities boom, controversial academic debates about natural resources and development prospered (ROSS, 2013; MENALDO, 2016). Latin American debates on neo-extractivism even provided development studies with a new theoretical contribution to the academic debate. In a nutshell, neo-extractivism focusses on a) the changes regarding scale and intensity of natural resource extraction and b) a modification of the state's role in natural resource governance (GUDYNAS, 2009; BURCHARDT; DIETZ, 2014).

On the one hand, at the end of the twentieth century, neoliberal reforms including natural resource governance reforms built the base for a process of intensified natural resource extraction in Latin America and the re-primarization of South American economies (ÁLVAREZ HUWILER; GODFRID; AND DUÁREZ, 2015, p. 173) that materialized at the beginning of the twenty-first century (Table No. 1). On the other hand, mirroring current developmental policies wisdom and past political initiative to reduce dependency of highly volatile international commodities prices, most Latin American counties in fact aimed to use natural resource income in order to diversify the economy during the last bonanza (PETERS, 2019, p. 185; ALARCÓN, 2020). Especially "progresista" governments followed a neoextractivist development strategy that consists of maximizing the government take of natural resource exports, strengthening the role of the state in the economy, using developmental planning in order to diversify the economy, and taking advantage of the increased financial leeway of the state to finance social development measures. 
Table No 1: Share of Exports of Primary Products in Total Exports (percentages)

\begin{tabular}{lllll}
\hline & $\mathbf{2 0 0 0}$ & $\mathbf{2 0 1 1}$ & $\mathbf{2 0 1 4}$ & $\mathbf{2 0 1 8}$ \\
\hline Argentina & 67,5 & 67,4 & 67,8 & $\mathbf{7 9 , 5}$ \\
\hline Bolivia & 71,1 & 94,5 & 94,3 & 92,7 \\
\hline Brazil & 41,6 & 65,9 & 65,2 & 63,9 \\
\hline Colombia & 67,5 & 80,6 & 82,4 & 79,3 \\
\hline Ecuador & 90,1 & 92,1 & 93,9 & 93,9 \\
\hline Mexico & 16,5 & 27,6 & 21,2 & 18,7 \\
\hline Paraguay & 92,5 & 92,4 & 90,5 & 88,3 \\
\hline Peru & 77,6 & 86,4 & 85,2 & 88,7 \\
\hline Uruguay & 58,1 & 72,0 & 76,3 & 77,7 \\
\hline Venezuela & 90,9 & 98,0 & 98,2 & n.a. \\
\hline
\end{tabular}

Source: CEPALSTAT (2020a).

The modernization effort undertaken during commodities booms resulted in the state pouring natural resources rent into the domestic economy. This, in turn, bankrolled what it might be called an "(up)lift effect", in which all social classes benefited to different degrees (BURCHARDT; DIETZ, 2014; CEPAL 2019, 28). Yet, the regional improvement of economic and social development achieved during commodities booms (e.g. the Gini index, the Human Development Index, the multidimensional poverty index) contrasts with debatable results in economic diversification, changing social structures, and the prevalence of the natural resources-based development model. In this line, when commodities booms are passé, they blatantly unveil the temporary character of such achievements. That is what has actually happened in Latin America. The hangover from the youngest commodities boom revives the discussion on dependence on natural resources and simultaneously invites to revisit the scope of the state's agency, i.e. its capacity to intervene in the national development process within the cycles of the capitalist world-economy. In what follows, we will provide an in-depth analysis of Ecuador as a paradigmatic case of a rentier society. 


\section{Modernization and Rent: The Political Economy of the Ecuadorian Oil Booms (1972- 1980 and 2003-2014)}

Ecuador is somehow a latecomer in the international oil business. However, after starting oil extraction at the beginning of the 1970 s the country transformed profoundly. The euphoria of the onrushing oil era is best illustrated in a 1971 New York Times' feature on Ecuador: "Oil Companies Find Ecuador's Long-Sought Eldorado" (MAIDENBERG, 1971). High hopes were set on the fact that multinational oil companies were already in place and the consortium Texaco-Gulf had started the construction of the $500 \mathrm{~km}$ Trans-Ecuadorian pipeline, from the Amazonia to the Pacific coast. Unlike in Venezuela5, where the government was allegedly "preparing to place the foreign oil operators under state control" (MAIDENBERG, 1971), private corporations seemed to expect a clear road in Ecuador.

In June 1970, José María Velasco Ibarra, who was elected in 1968 for the fifth time for the post of president, declared himself dictator with support of the armed forces, whom he offered 50 percent of the expected oil royalties (BÁEZ, 1984, p. 93). However, Conaghan (1988, p. 79) argued that as the possibility of massive oil exportation approached, "military's fears were focused on the specter of civilian politicians pillaging [oil] windfall revenues pouring into the state". Indeed, the oil bonanza was not to be left in hands of the civilian dictator. Ecuador followed a course set by the majority of Latin American countries during the 1970s; with few exceptions (e.g. Costa Rica, Venezuela), authoritarian regimes, mostly in the form of military dictatorships, ruled over the region. General Guillermo Rodríguez Lara led a military coup that overthrew Velasco Ibarra, and installed the self-styled "revolutionary nationalist" government in February 1972. A central concern of the novel dictatorship consisted in the state's capture of oil rent. Following the nationalist trend that prevailed in petro-states all over the world at that time (ARBATLI, 2018, 103), the "revolutionary nationalist" dictatorship claimed state's ownership of subsoil natural resources. The principal strategy that the dictatorship grasped at in order to appropriate a larger portion of oil rent was the creation of the state oil company just one month before the inauguration of the

\footnotetext{
5 Whereas the Ecuadorian oil era began with its first oil boom in 1972, Venezuela's oil era began in the early
} 1920 (TINKER SALAS, 2009). 
Trans-Ecuadorian pipeline ${ }^{6}$. With the renegotiation of the contract with Texaco-Gulf, the Ecuadorian state was allowed to purchase a 25 percent share of the consortium. As Gulf retired in 1977, the government acquired its share and the participation of the state in the oil profits reached 62.5 percent $^{7}$. This was accompanied by the integration into the Organization of Petroleum Exporting Countries (OPEC), which acts as a cartel in order to exert pressure on importing countries to recognize a higher value of oil rent for exporting countries.

With oil rent at its disposal, the "revolutionary nationalist" dictatorship embarked the country in the industrial society paradigm. The appropriation of considerable portion of rent income turned the state into a powerful development agent. Crucial ingredients were the dictatorship's faith in economic planning and the transference of oil rent from the primary sector to other parts of the economy. Thanks to the enforcement of one of the "most generous" sets of measures to back industrialists in Latin America (WORLD BANK, 1980, p. 253), which included exemptions from tariff and import duties, tax benefits, and subsidies (e.g. on industrial electricity and oil products for industrial use), the manufacturing sector expanded ${ }^{8}$ during the first oil boom (Table No. 2).

${ }^{6}$ Other principal strategies were the shift from concession schemes to contractual schemes, and the renegotiation of contracts with foreign oil companies.

7 For comparison, oil nationalizations worldwide had its golden years in the 196os and 1970s (ROSS, $2012, \mathrm{p}$. 39). Expropriations raised the states' share of oil profits from 50 percent in the early 19605 to 98 percent in average in 1974 (MOMMER, 2002). Forerunners of oil nationalization in Latin America were Argentina in 1910, Bolivia in 1937, and Mexico in 1938 (ROSS, 2013, p. 37).

8 The expansion of the manufacturing sector during the first Ecuadorian oil boom, i.e. the increase of its share in the domestic GDP, is an argument that sets the resource curse thesis into question. The resource curse thesis affirms that natural resources-based development models hinder economic diversification and industrialization (AUTY, 1993). 
Table No. 2: Gross value added by sector (as percentage of GDP), 2007 U.S. dollars, selected years, Ecuador 1972-2016

\begin{tabular}{|c|c|c|c|c|c|c|c|}
\hline \multirow[t]{2}{*}{ Economic sector } & \multicolumn{7}{|c|}{ Value added (percent) } \\
\hline & 1972 & 1981 & 1988 & 1994 & 2000 & 2007 & 2016 \\
\hline $\begin{array}{l}\text { Agriculture (includes livestock, fishing, and } \\
\text { forestry) }\end{array}$ & 10.7 & 6.7 & 7.4 & 8.3 & $9 \cdot 4$ & 9.4 & $9 \cdot 4$ \\
\hline Petroleum and mining & 6.0 & $9 \cdot 3$ & 11.7 & 12.2 & 10.2 & 11.7 & 10.2 \\
\hline Manufacturing & 12.6 & 13.8 & $13 \cdot 4$ & $14 \cdot 3$ & $15 \cdot 2$ & 13.7 & 13.2 \\
\hline Construction & 16.0 & 9.8 & $7 \cdot 7$ & 6.3 & 6.0 & $7 \cdot 9$ & $9 \cdot 4$ \\
\hline Utilities & 0.9 & 0.2 & 1.2 & 1.1 & 1.4 & 1.1 & 2.8 \\
\hline $\begin{array}{l}\text { Tertiary sector (includes commerce, } \\
\text { government services, transport, other } \\
\text { services) }\end{array}$ & 53.8 & 60.2 & 58.6 & 57.8 & 57.8 & 56.2 & 55.0 \\
\hline
\end{tabular}

Source: BCE (2020)

Though, growth resulted from a transient upsurge in already dominant industrial segments in a context of domestic demand expansion, i.e. small- and medium-sized industries of finished consumer goods, such as food processing and textiles and clothing (ALARCÓN, 2020, p. 122). Hence, the temporary expansion of the manufacturing sector did not mean the takeoff of the domestic industry, nor did it represent a significant change in the country's industrial profile (FERNÁNDEZ, 1989, p. 201). The other side of the coin was increasing external debt and the country's snowballing dependence on imports of manufactured goods.

The modernization effort undertaken by the state during the first Ecuadorian boom (1972-1980) enhanced the domestic market; household consumption was boosted as the state poured oil rent into (almost) all social classes. On the one hand, modern urban middle classes emerged as the winners of the bonanza period (ALARCÓN, 2020; OLEAS MONTALVO, 2013, p. 39). On the other hand, indigenous peoples were excluded from the rentier modernization project9; in September 1972, General Rodríguez Lara asserted that

9 The negation of indigenas in the national modernization project converged with a widespread current of thought that linked indigenous peoples with backwardness and archaic societies (STAVENHAGEN, 1979, p. 23). 
"there is no more Indian problem, we all become white when we accept the goals of national culture" (STUTZMAN, 1981, p. 45).

The natural resources-led modernization endeavor resumed during the second Ecuadorian oil boom, which coincided with the "commodities super-cycle" 2003-2014. As well as during the 1970s, the Ecuadorian state strove for the appropriation of a larger portion of oil rent, and (again) pursued economic diversification. A landmark in the direction of the state's recovery of oil rent took place in 2006. The government of President Alfredo Palacio cancelled the contract with Occidental Petroleum Corporation (OXY) after accusing the multinational of violating the Hydrocarbons Law. By taking over OXY's operations, the state company recovered about one fifth of Ecuador's total oil output. Another pointer to the return of the "effective landlord" was Ecuador's readmission ${ }^{10}$ to OPEC in 2007. Both milestones in the state's claim for a larger portion of oil rent converged toward the nationalist trend triggered by the democratic "left turn" of a significant portion of the region ${ }^{11}$.

However, part of the improvements should prove to be a constraint in disguise. Correa's government bargained credits with foreign oil companies (Chinese companies PetroChina Co. Ltd. and Sinopec Corp., and Thailand's state-run PTT) since 2009. This poured important amounts of foreign exchange into the state coffers at the cost of presale orders of oil. Short-term development opportunities jeopardized thereby the state's landlord condition for the future. As a result, Asian oil companies take a large part of Ecuadorian crude exports as debt agreements that are repaid with oil (OROZCO, 2018; VALENCIA, 2017; VALENCIA, 2015). Biddings were conducted in secrecy; this, added to the volatile nature of international oil prices might have caused underestimation of the country's external debt.

The new fiscal leeway was accompanied by a second attempt of economic diversification. However, external conditions soon proved to be a straitjacket. First, economic globalization became a growing hindrance to the enforcement of state's protectionist measures, and second, technological advance set the pace for industrial development, and the incorporation of technology (together with an increase in productivity) became the

\footnotetext{
${ }^{10}$ In 1992, Ecuador abandoned OPEC in a bet to counteract plummeting international oil prices with increased oil exports without any quota restriction.

${ }^{11}$ According to Levitsky and Roberts (2011, 1), the "wave" began in 1998 when Hugo Chávez was elected president of Venezuela.
} 
measure of competitiveness within the globalized world economy. These external constraints forced the reassessment of the industrial society paradigm not only in Ecuador, but at regional level. Compared to its Latin American fellows, the Ecuadorian state seemed like a model student, analyzing macroeconomic textbooks and applying policy recommendations. Correa's government set its best bet on a boost to the investments in tertiary education as a main strategy to pursue the cambio de la matriz productiva (transformation of productive structure). Therefore, the government relied on important investments in research and development. Actually, Correa's government founded the University of Research of Experimental Technology Yachay (knowledge), which was envisioned as the center of the cambio de la matriz productiva. The promotion of tertiary education was complemented with an ambitious program of international scholarships, which was meant to form a generation to lead the transit to the industrial society by benefiting about 13,000 students between 2007 and 2018. Though, the government's rhetoric towards the private sector did not include the question if it might be able to absorb the return of the highly-qualified troop of scholarship holders. Neither the new state university with its oversized campus, nor the freshly returned highly qualified professionals have yet revitalized the sluggish manufactured sector, which follows a decreasing trend since the beginning of the century (Table No. 2).

Moreover, the state tried to promote national production by making use of additional policy measures, including subsidies for local production and protection through import tariffs. However, the results remained poor. A telling example is the project to promote the use of induction cookers and their production in Ecuador. The objective was twofold: First it should boost a national production, and second it aimed to reduce domestic gas ${ }^{12}$ (liquefied petroleum gas, LPG) consumption and make use of the country's hydroelectric resources. Although the state offered generous subsidies for national business interested in producing induction cookers, the project did not prosper. Business preferred to maintain in rentier rather than in productive activities. In the end the government opted to import induction cookers from China (PURCELL et al. 2017).

\footnotetext{
${ }^{12}$ Liquefied petroleum gas (LPG) is massively used by households in Ecuador for cooking.
} 
Contrasting with the disappointing results of economic diversification (Table No. 2), the creation of public employment opportunities was central to the enhancement and strengthening of modern urban middle classes. The task of economic planning was to ensure the transference of rent income to politically prioritized sectors, as the oil bonanza enabled the massive flow of state resources to the public sector. By 2009, Correa's government already established 21 new state entities (seven ministries of coordination, five sectorial ministries, two national secretariats, and seven state's or technical secretariats $\left.{ }^{13}\right)$. Until the end of its administration in 2017, Correa's government created at least 50 new state entities, including public enterprises, agencies, councils, research institutes, and four state universities (HURTADO, 2017, p. 489; TIBÁN, 2018), as upward adjustments in remunerations took place $^{14}$. Moreover huge investments in infrastructure (roads, electricity generation, airports, Quito subway, etc.) were a further pillar of the government's developmental project, whereas construction also benefitted from a housing boom typically for oil booms all over the world.

Upper and middle classes also continued to benefit disproportionally from fuel subsidies and relatively low taxation (DI BELLA et al. 2015, p. 10; CANO, 2017). As during the first oil boom, increasing public investment turned the state into the motor of the economy. Therefore, business relied mainly on the state:

The profit of the government is unprecedented and can be unbelievable. Just by taking a 'walk' through the facilities of the Ministry of Industry and Productivity, one can see the long lines of dozens of company owners or its representatives trying to find a positive negotiation by the executive. [...] It has become necessary to learn about the government, and build or try to build a close relationship based on confidence in order to avoid possible future affectations (POVEDA, 2014).

Poveda's observation has to be read also in line with polarization and the interest to scapegoat Correa's government. However, it confirms a general trait of state-business relations in rentier societies as highlighted by Coronil (2008, p. 3): "If in capitalist nations based on the generation of value through human labor the business of politics is business, in

\footnotetext{
${ }^{13}$ Among the new nine secretariats was the Secretaría del Buen Vivir. For comparison, Germany has 15 ministries, including the Federal Chancellery (Bundeskanzleramt) (ICKLER; MATTHES, 2019, p. 178).

${ }^{14}$ An assessment of the number of new public employees during Correa's government is especially difficult to carry out since the majority of them were non-tenured. The figure of the consultor was widespread in order to limit contracts to six months or one year. However, Ospina Peralta (2013, p. 236) estimated 98,784 new hires between December 2006 and December 2010.
} 
oil exporting societies based on the extraction of rents through the capture of natural riches, the business of business is politics." However, the renewed state-led boost of the internal market added to the increasing technological gap and resulted in deepening the dependence on imports of manufactured products (even for household consumption).

\section{The Rentier Bargain and the Limits to Reform}

The growing fiscal deficit left by the dramatic drop in international oil prices of 2014 questioned the long-term prevalence of the socioeconomic achievements attained during the second oil boom, such as the consolidation and strengthening of middle classes, and even the reduction of poverty (DOMÍNGUEZ; CARIA, 2016). In such context, external debt resources proved to be central to maintain state benefits of middle and lower classes (particularly those related to employment opportunities in the public sector and subsidies on oil products).

In 2017, Lenín Moreno, Correa's vice president between 2007 and 2013, assumed office after winning the 2016 presidential election. With a hefty debt burden and with a significant portion of national oil rent already compromised, Moreno began his administration with limited room for maneuver. After failing to renegotiate debt conditions with China, Moreno's government decided to opt for neoliberal measures and reverted to the International Monetary Fund (IMF) and reached a US\$ 4.2 billion deal (REUTERS, 2019; LONG, 2019; PONCE, et al, 2020). In order to plead for fund's disbursements, the government is compelled to meet the well-known ${ }^{15}$ requisites of coping with a) the size of the state apparatus and b) the state's policy on subsidies.

The ongoing pursuit of a smaller state counted already 16,000 layoffs in the public sector by the beginning of August 2019 (El Comercio, August 4, 2019), and further set its sights on public enterprises ${ }^{16}$. Between December 2018 and July 2019, about 6,500 public servants have been removed from public companies in an alleged optimization. According to

\footnotetext{
15 During the last decades of the twentieth century, the IMF was the spearhead of the enforcement of Washington Consensus' policies.

${ }^{16}$ The dismantlement of the bunch of ministries and state entities created during the previous decade not only impacted on the middle classes and slackened the pace of household consumption, but also sent a strong message of Moreno's departure from his predecessor.
} 
government officials, the payroll of circa 33,500 employees at public enterprises (by August 2019) is "still obese" (MONTENEGRO, 2019). Moreover, in the 2019 neoliberal reform package, public worker's holidays were reduced by half (Ponce et al. 2020) and in 2020 even wages were reduced alleging a cut in the working hours.

The crisis of the end of the twentieth century had shown that mass dismissals in the public sector mean no social explosion. However, the case of subsidies on oil products is another story; when Moreno and his allies picked out subsidies on transportation fuels (gasoline and diesel), they evidently underestimated social reaction ${ }^{17}$. To be granted subsidies on oil products for domestic use has been regarded as a quasi-naturalized right by peoples living in oil exporting countries (for a similar argument on Venezuela, see) (BAUTISTA URBANEJA, 2013). Indeed, subsidies on diesel, gasoline, and domestic gas (LPG), which are broadly used by households in public transportation (diesel), in family cars (gasoline), and in cooking (LPG) have been maintained for nearly fifty years in Ecuador as a landmark of its oil era.

Though, the country's oil refining capacity has never been sufficient to meet the domestic demand of oil products. The gap between domestic demand and supply has been historically covered by imports. This became the paradox of the Ecuadorian oil era: An oil exporting country that imports oil products; a peripheral natural resources-rich country, which depends on imports of manufactured products. Since the start of commercial operations of the state-owned Refinería Estatal de Esmeraldas in 1978, in the first Ecuadorian oil boom, no significant refining capacity has been further added. During the second oil boom, such big step in the direction of the industrial society paradigm was meant to be surpassed with the Refinería del Pacifico; the planned new state-owned refinery was declared a national priority at the beginning of Correa's government, and its inauguration was planned

\footnotetext{
${ }_{17}$ President Moreno was advised that the elimination of subsidies on transportation fuels might cause discontent principally among indigenous peoples, allegedly, a minor portion of the population. As mentioned before, indígenas became indeed the spearhead of the protests; their massive mobilization from the highlands to Quito not only paralyzed the city during two weeks, but also triggered fears of shortages. During the siege, which ended with the announcement of the repeal of the measure, indigenas were supported (not only logistically) by ample sectors of urban middle classes. It is unclear if Moreno and his allies learned a lesson from recent economic history; when President Abdalá Bucaram eliminated the subsidy on domestic gas for cooking in 1997, he tossed a stick of dynamite into a tinderbox. Few days later he was removed from office. Amid nationwide protests, the National Assembly declared Bucaram "mentally incapacitated" (loco).
} 
for 2017. Though, despite an outlay amounted to over US\$1.5 billion, the construction of the refinery never begun (PACHECO, 2019).

Due to the stagnation of the domestic refining capacity, imports of oil products, mainly LPG and transportation fuels (diesel and gasoline), jumped from 2.1 million barrels in 1978 to the historical peak of 57.1 million barrels in 2014 (BCE, 2017, p. 197). The case of transportation fuels during the twenty-first century is dramatic. The Ecuadorian state imported 17 percent of the country's demand of diesel in 2000; by 2015 imported diesel amounted to 69 percent of domestic demand. The figures for imports of gasoline skyrocketed from 10 percent in 2000 to 70 percent in $2015^{18}$ (ESPINOZA; GUAYANLEMA 2017, p. 7).

The Ecuadorian state purchases diesel and gasoline at international prices and offers them to households at a fixed subsidized price; with about US\$0.27 and US\$0.49 per liter, respectively. Diesel and gasoline in Ecuador are the second cheapest in South America ${ }^{19}$ only after Venezuela (GLOBALPETROLPRICES, 2020a; GLOBALPETROLPRICES, 2020b). Hence, the fiscal pressure is snowballing. The cost of importing oil products (diesel, gasoline, and LPG) jumped from circa 1.7 percent of GDP by the beginning of the twenty-first century to 5.4 percent of GDP in average during the period 2011-15 (ESPINOZA; GUAYANLEMA, 2017, p. 13-17). For comparison, in 2011, public expenditure of the central government in education and health amounted 4.4 and 1.5 percent of GDP, respectively and reached 4.5 (education) and 2.5 (health) until 2015 (CEPALSTAT, 2020b). The consequences of spending more than the double on fuel subsidies compared to public health became terribly obvious in the 2020 corona-crisis.

There is huge agreement in Ecuador about the unequal nature of subsidies on transportation fuels and their regressive distributional effects ${ }^{20}$. The argument is

${ }^{18}$ Imports of LPG increased from 60 percent in 2000 to 87 percent in 2015 (ESPINOZA; GUAYANLEMA $2017, p$. 7).

${ }^{19}$ Liquefied petroleum gas (LPG) for cooking constitutes another significant example of a subsidy that benefits households. The $15 \mathrm{~kg}$-cylinder is marketed domestically at a fixed price of US\$1.60; the Ecuadorian state pays at least ten times more for the same amount of LPG in international markets.

${ }^{20}$ Besides socioeconomic inequalities, Alarcón (2011) drew attention to the socio-environmental inequalities related to subsidies on transportation fuels in Quito. The amount of emissions of global and local contaminants linked to the use of household cars exceeds (per person) that of public transport systems. A main reason is that middle and upper class households own more than one car per family, and thus cars are used practically as individual cars in Quito. 
straightforward: whereas upper and middle classes benefit from a larger portion of state resources entailed in subsidies on gasoline and diesel for private cars, lower classes benefit indirectly from low-cost public transport, which receives subsidized diese ${ }^{21}$. The amount of the compensation received by upper and middle classes depends on the number of private cars owned by a household, while lower classes "enjoy" low quality and low comfort public transport. Moreover, in a recent study on Venezuela, Peters $(2017,59)$ drew attention to other theoretical objections to the maintenance of subsidies on transportation fuels, which apply to Ecuador as well. Fuel subsidies cause high incentives for smugglers, and for lavish and wasteful energy use. Yet, despite all kinds of concerns, political (high political costs of their elimination), economic (contraband), financial (fiscal pressure), socioeconomic (regressive distributional effects), socio-environmental (emissions of global and local contaminants), socio-cultural (lavish and wasteful energy use), Moreno's attempt ${ }^{22}$ to eliminate subsidies on transportation fuels did not echo on society ${ }^{23}$. One part of the story is that prices for diesel were to be increased substantially more (123 percent) than prices for gasoline (29 percent) despite the latter's more regressive distributional effect (PONCE et al. 2020). However, we cannot understand the importance of fuel price increases by only focusing on the numbers. Society cannot be reduced to pure math.

This puzzle might be solved by considering the deep rooted conviction that cheap energy is a quasi-naturalized right for Ecuadorians backed by the fact that they were born in an oil-country. Put differently, path dependency permeates the socio-cultural attitudes. Society's claim on the maintenance of the subsidies is the corollary of the rentier bargain between the state and society, which prevails since the dawn of the Ecuadorian oil era. In such long-term arrangement, state's rent distribution in the form of subsidies nurtured society's expectancies and created quasi-naturalized rights. In a context of prevalence of

\footnotetext{
${ }^{21}$ The public transportation fare in Quito has remained unchanged since 2003 at US\$ 0.25 .

${ }^{22}$ Further research might be undertaken on the strategies Moreno's government deployed in order not to be toppled. Recent economic history shows that no administration could withstand social protest for so long, particularly when the indigenous movement played a central role. For comparison, when President Bucaram scrapped subsidies on domestic gas in 1997, he was removed only a couple of days after social protests begun.

${ }^{23}$ Even the Ecuadorian environmental movement rejected the elimination of subsidies on transportation fuels. When protests arose, Moreno tried to present the measure as a key component of the government's environmental policy in order to gain support of the environmental movement. Activists, who belong mostly to urban higher and middle classes, publicly confirmed that there was no previous deal, and adhered to the cause of the indigenous movement.
} 
economic, social, ethnic, and status inequalities, the access to benefits of the rentier state (even the access to social security, public health, and public education) is highly unequal; then, the struggle for the preservation of subsidies on fuels might be regarded as a step on the relentless quest for universal access to state benefits.

Given a weak fiscal contract, in which the state does not depend on the national economy, the government's attempt of demanding a stronger contribution from society (in the form of the elimination of subsidies) deeply questions the foundations of the longstanding rentier bargain; then the status quo trembles, and people rush into the streets. This also calls into question the idea of a high degree of autonomy of the rentier state in relation to society ${ }^{24}$, i.e. its capacity to act independently of society without depending on the democratic participation of its citizens for legitimacy (PETERS, 2017). In this line, the distribution of oil rent (in the form of subsidies or other state benefits) proved to be central to enable the state to impose its decisions, and even the direction of the national development project.

With low international commodities prices and external debt throttling state coffers, the possibilities of the rentier state of offering constitutionally prescribed rights, such as social security, public health, and public education, to all citizens seem further away. Then, compensatory state benefits (or even perks) might turn into the barometer of the relationship between the state and society.

\section{Conclusion: Lessons From the Global South}

The recent commodity price cycle once again confirmed natural resources-based development models to be crisis prone. The last commodities boom brought impressive economic growth rates that - especially in Latin America - were accompanied with important social development gains, political change and in some cases even the (discursive) embracement of alternative visions of development based on the indigenous cosmovision ${ }^{25}$.

\footnotetext{
${ }^{24}$ Plummeting international oil prices blatantly exposed the loss of autonomy of the Ecuadorian state in relation to international financial institutions (IFI), whereas the closeness with lenders of last resort confirmed that debt agreements to be repaid with oil put the state's landlord condition in jeopardy.

${ }^{25}$ At the dawn of the twenty-first century commodities boom, the domestic juncture was shaped by two settings that were highly unlikely during the 1970s. First, indigenous peoples were firmly entrenched in national politics; second, the Ecuadorian state had embraced the official environmental discourse of sustainable
} 
Arguably, Rafael Correa's government in Ecuador can be considered as a posterchild of a neoextractivist development model/strategy. The government aimed to make use of oil money in order to a) foster structural change of the economy (by leaving behind dependence on natural resource exports), b) promote social development and even c) support ambitious objectives in terms of environmental protection. Although some important gains, especially regarding social development have been reached, the overall balance remains rather disappointing. Economic diversification failed and at the end of the boom the country was highly indebted.

Political analysts often explain the poor results highlighting policy failure and scapegoating Correa's government. No doubt, that there is a lot of space for critique of concrete measures and an arguably authoritarian style of Correa. However, the article highlights the underlying reasons for a repeated history of missed opportunities during oil booms. Economic diversification fails due to the reproduction of rentier economy patterns, the state's focus on rent distribution and further due to the initial rentier bargain. Rentier theory offers important insights, yet, it generally focusses on economic and political explanations, underestimating social and social-culture factors. Based on our in-depth analysis of the Ecuadorian case study, we highlight the potential of an analysis of a rentier society that links political economy with social and socio-cultural factors. Further research should broaden the empirical basis of the central arguments presented in this article, by analyzing other rentier societies both in case studies or small-N- comparisons.

Recent developments in the Global South outline that the analytical framework may help to understand social dynamics in rentier societies, although there are surely important

development, which decisively contributed to boost environmental awareness among the Ecuadorian society. Both facts are central to understand the assumption to power of the new left-leaning President Rafael Correa in 2007, and the draft of the new 2008 Constitution. A particular interpretation of the indigenous worldview of the Good Living (Buen Vivir) was meant to become the guiding thread of the 2008 Constitution and the general guideline of the self-styled government of the "citizens' revolution". This alternative-to-development vision entails an influential socioecological dimension based on a harmonic relation between society and nature; though, concurring with its inclusion in the constitution and other official documents (e.g. national development plans) the concept of Buen Vivir was despoiled of its "critic and transformer potential" (PETERS, 2014, 140) and gradually faded away by suggesting rather development alternatives (instead of alternatives to development) such as sustainable development (ALARCÓN; MANTILLA 2017, p. 101) and human development (CORTEZ, 2014, p. 338). Despite Buen Vivir's influential socioecological dimension, the embarkment on the "industrial society paradigm" during the second Ecuadorian oil boom relied mainly on rent income from oil extractivism. 
variance that has to be analyzed with more detail. For instance, recent protests suggest a wider scope of concerns of society and even a demand for more participation in key decisions on the direction of the national development project. Protests exhibited deferred social demands (such as access to public health, or unveiled high costs of health). In Ecuador, fears of a generalized escalation of prices in a context of rising unemployment added to other concerns related to the "high cost of living". Chile provides a paradigmatic case of the course of the protests in Latin America; a minor increase in the urban transportation fare triggered social mobilizations that lasted for weeks, where citizens complained about the prohibitive costs of education and health that they have to pay with their meager remunerations in the context of an absent state.

Besides concerns of society, protests also shed light on the possible reactions of the state. Iran, a textbook case of a rentier society, provides a grim example of a crackdown on social protest against the elimination of compensatory state benefits. A surprise increase in officially set gasoline prices announced on November $15^{\text {th }} 2019$ triggered widespread demonstrations, which soon broadened and mirrored other problems such as social repression and corruption (FASSIHI, 2019; KADIVAR et al. 2019). The "brutal crackdown" left circa 200 people dead and 2,000 arrested (FASSIHI; GLADSTONE, 2019); thereby, the Iranian regime acknowledged that its security forces "shot and killed protesters across the country to put down demonstrations" (ASSOCIATED PRESS, 2019).

\section{References}

AHMADOV, Anar K. Oil, Democracy, and Context: A Meta-Analysis. Comparative Political Studies, [s.I.], v. 47, n. 9, p. 1238-1267, 2014.

ALARCÓN, Pedro. Movilidad urbana, consumo de energía y calidad del aire. Letras verdes. Revista Latinoamericana de Estudios Socioambientales, [s.I.], v. 8, p. 15-17, 2011.

ALARCÓN, Pedro. Rent and the State: An Approach to the Ecuadorian Oil Booms and Their Impact on Social Formation. PhD diss., Facultad Latinoamericana de Ciencias Sociales sede Ecuador, 2020.

ALARCÓN, Pedro; MANTILLA, Renata. El discurso ambiental en el gobierno de la revolución ciudadana. Iberoamérica social. Revista-red de estudios sociales, [s.I.], v. 7, n. 4, p. 91-107, 2017. 
ÁLVAREZ HUWILER, Laura; GODFRID, Julieta; DUÁREZ, Jorge. Expansión minera y protesta social en Argentina y Perú. Investigaciones Sociales, Lima, v. 19, n. 35, p. 169-186, 2015 .

AMIN, Samir. Delinking: Towards a Polycentric World. London: Zed Books, 1990.

ARBATLI, Ekim. Resource nationalism revisited: A new conceptualization in light of changing actors and strategies in the oil industry. Energy Research \& Social Science, [s.I.], v. 40, p. 101-108, 2018.

ASSOCIATED PRESS. Iran admits killing 'rioters' during gas-price protests. Los Angeles Times, [s.l.], 3 dec., 2019. Available in: https://www.latimes.com/world-nation/story/201912-03/iran-protests-deaths . Last accessed: 17 apr. 2020.

AUTY, Richard. Sustaining Development in Mineral Economies: The Resource Curse Thesis. London: Routledge, 1993.

BÁEZ, René. Dialéctica de la economía ecuatoriana. Tercera edición. Quito: Editorial Alberto Crespo Encalada, 1984.

BANCO CENTRAL DEL ECUADOR (BCE). Cuentas Nacionales No. 24. A precios de 2007. Quito: Banco Central del Ecuador, 2020. Available in: https://contenido.bce.fin.ec/documentos/PublicacionesNotas/Catalogo/CuentasNacionales/ Anuales/Dolares/indicecn1.htm. Last accessed: 13 jul. 2019.

BANCO CENTRAL DEL ECUADOR (BCE). Noventa años del Banco Central del Ecuador. Series estadísticas históricas 1927-2017. Quito: Banco Central del Ecuador, 2017.

BAPTISTA, Asdrúbal. Teoría económica del capitalismo rentístico. Caracas: Banco Central de Venezuela, 2010 (1997).

BAUTISTA URBANEJA, Diego. La renta y el reclamo. Ensayo sobre petróleo y economía política en Venezuela. Caracas: Alfa, 2013.

BEBLAWI, Hazem; LUCIANI, Giacomo. The Rentier State in the Arab World. London: Croom Helm, 1987.

BECKER, Joachim. Der kapitalistische Staat in der Peripherie: polit-ökonomische Perspektiven. Journal für Entwicklungspolitik, [s.I.], v. 25, n. 2, p. 10-32, 2008.

BURCHARDT, Hans-Jürgen; DIETZ, Kristina. (Neo-)extractivism - A New Challenge for Development Theory from Latin America. Third World Quarterly, [s.I.], v. 35, n. 3, p. 468486, 2014 .

CANO, Liliana. Impuesto sobre la renta de las personas físicas y desigualdad de los ingresos en el Ecuador entre 2007 y 2011. Revista de la CEPAL, [s.I.], v. 123, p. 59-82, 2017.

CANUTO, Otaviano. The Commodity Super-Cycle: Is This Time Different?. Economic Premise, [s.I.], v. 150, p. 1-3, 2014. 
CARDOSO, Fernando Henrique. Ideologías de la burguesía industrial en sociedades dependientes (Argentina y Brasil). México D.F.: Siglo XXI, 1971.

CEPAL - COMISIÓN ECONÓMICA PARA AMÉRICA LATINA Y EL CARIBE. Panorama Social de América Latina y el Caribe 2019. Santiago de Chile: CEPAL, 2019.

CEPALSTAT. Exports of primary products as a share of total exports: Percentages of the total value of f.o.b. exports of goods. Santiago de Chile: CEPAL, 2020a. Available in: https://cepalstat=prod.cepal.org/cepalstat/tabulador/Consultalntegrada.asp?IdAplicacion= 6\&idTema=119\&idlndicador=1910\&idioma=i . Last accessed: 21 abr. 2020.

CEPALSTAT. Public expenditure according to the classification of the functions of government (as a percentage of GDP). Santiago de Chile: CEPAL, 2020b. Available in: https://cepalstatprod.cepal.org/cepalstat/tabulador/Consultalntegrada.asp?idlndicador $=312$ Z\&idioma=i . Last accessed: 13 mar.2020.

CONAGHAN, Catherine. Restructuring Domination: Industrialists and the State in Ecuador. Pittsburgh: University of Pittsburgh Press, 1988.

CORONIL, Fernando. It's the Oil, Stupid!!!. ReVista. Harvard Review of Latin America, [s.I.], v. 8, n. 1, p. 19-20, 2008.

CORONIL, Fernando. The Magical State: Nature, Money and Modernity in Venezuela. Chicago: The University of Chicago Press, 1997..

CORTEZ, David. Genealogía del sumak kawsay y el buen vivir en Ecuador: un balance. In: ENDARA, Gustavo (coord.). Post-crecimiento y buen vivir. Propuestas globales para la construcción de sociedades equitativas y sustentables. Quito: FES-ILDIS, 2014. p. 315-52.

DAILY EL COMERCIO. 2019. En julio, el déficit presupuestario se incrementó en USD 500 millones. Quito, 4 aug. 2019.

DI BELLA, Gabriel; NORTON, Lawrence; NTAMATUNGIRO, Joseph; OGAWA, Sumiko; SAMAKE, Issouf; SANTORO, Marika. 2015. Energy Subsidies in Latin America and the Caribbean: Stocktaking and Policy Change. Washington DC: International Monetary Fund. n. 15-30, 2015.IMF Working Paper.

DOMÍNGUEZ, Rafael; CARIA, Sara. Extractivismos andinos y limitantes del cambio estructural. In: BURCHARDT, Hans-Jürgen; DOMÍNGUEZ, Rafael; LARREA, Carlos; PETERS, Stefan (edited by). Nada dura para siempre. Neo-extractivismo tras el boom de las materias primas. Quito: Universidad Andina Simón Bolivar sede Ecuador, International Center for Development and Decent Work, 2016. p.89-129.

ELSENHANS, Hartmut. Rente, strukturelle Heterogenität und Staat: Entwicklungsperspektiven der Staatsklassen in der Dritten Welt. Journal für Entwicklungspolitik, [s.I.], v. 4, p. 21-36, 1986.

ERTEN, Bilge; OCAMPO, José Antonio. Super-Cycles of Commodity Prices since the MidNineteenth Century. World Development, [s.I.], v. 44, p. 14-30, 2013. 
ESPAÑA, Sara. El coronavirus desborda Ecuador y abruma a su población por la acumulación de cadáveres en casas. El País, [s.I.], 1 apr. 2020. Available in: https://elpais.com/sociedad/2020-04-01/el-coronavirus-desborda-ecuador-y-abruma-a-supoblacion-por-la-acumulacion-de-cadaveres-en-casas.html. Last accessed: 23 apr. 2020.

ESPINOZA, Sebastián; GUAYANLEMA, Verónica. Balance y proyecciones del sistema de subsidios energéticos en Ecuador. Quito: FES-ILDIS, 2017.

FASSIHI, Farnaz. Protests Incited by Gas Price Hike Grip Iran. The New York Times, [s.I.], 16 nov. 2019. Available in: https://www.nytimes.com/2019/11/16/world/middleeast/iran-gasprice.html. Last accessed: 17 apr. 2020.

FASSIHI, Farnaz; GLADSTONE, Rick. 2019. With Brutal Crackdown, Iran Is Convulsed by Worst Unrest in 40 Years. The New York Times, [s.l.], 3 dec. 2019. Available in: https://www.nytimes.com/2019/12/01/world/middleeast/iran-protests-deaths.html. Last accessed: 17 apr. 2020.

FERNÁNDEZ, Jorge. 1989. "Estado e industrialización." In: MAURO, Amalia (edit.). La investigación económica en el Ecuador. Quito: ILDIS, 1989. p. 191-210.

FRANK, André Gunder. Lumpenbourgeoisie: Lumpendevelopment: Dependence, Class and Politics in Latin America. New York: Monthly Review Press, 1972.

GALEANO, Eduardo. Las venas abiertas de América Latina. Third edition. Ciudad de México: Siglo XXI, 2014.

GLOBALPETROLPRICES. 2020b. Gasoline prices, liter, 20-Apr-2020. [S.I.], 27 apr. $2020 \mathrm{~b}$. Available in: https://www.globalpetrolprices.com/gasoline prices/, last accessed: 27 apr. 202ob.

GLOBALPETROLPRICES. Diesel prices, liter, 20-Apr-2020. [S.I.], 27 apr. 2020a. Available in: https://www.globalpetrolprices.com/diesel_prices/ . Last accessed: 27 apr. $2020 a$.

GOPINATH, Gita. 2020. The Great Lockdown: Worst Economic Downturn Since the Great Depression. IMFBlog, [S.I.], 14 apr. 2020. Available in: https://blogs.imf.org/2020/04/14/thegreat-lockdown-worst-economic-downturn-since-the-great-depression/, Last accessed: 24 apr. 2020.

GUDYNAS, Eduardo. Diez tesis urgentes sobre el nuevo extractivismo. Contextos y demandas bajo el nuevo progresismo sudamericano actual. In: SCHULDT, Jürgen; ACOSTA, Alberto; BARANDIARÁN, Alberto; BEBBINGTON, Anthony; FOLCHI, Mauricio; ALAYZA, Alejandra; GUDYNAS, Eduardo (edit.). Extractivismo, política y sociedad. Quito: Centro Andino de Acción Popular (CAAP) - Centro Latinoamericano de Ecología Social (CLAES), 2009. p. 187-225.

HERB, Michael. No Representation Without Taxation? Rents, Development and Democracy. Comparative Politics, [s.I.], v. 37, n. 3, p. 297-316, 2005. 
HERB, Michael. The Wages of Oil. Parliaments and Economic Development in Kuwait and the UAE. Ithaca: Cornell University Press, 2014.

HUMPHREYS, Macartan; SACHS, Jeffrey; STIGLITZ, Joseph. Escaping the Resource Curse. New York: Columbia University Press, 2007.

HURTADO, Osvaldo. Ecuador entre dos siglos. Bogotá: Penguin Random House, 2017.

HVIDT, Martin. Economic diversification in the GCC countries-past record and future trends: Research Paper No. 27: Kuwait Programme on Development, Governance and Globalisation in the Gulf States, 2013.

KADIVAR, Mohammad Ali; KHANI, Saber; SOTOUDEH, Abolfazl. Iran's Protests Are Not Just About Gas Prices: Repression Won't Solve the Deeper Problems Bringing Iranians to the Streets. Foreign Affairs, [s.l.], 4 dec, 2019. Available in:

https://www.foreignaffairs.com/articles/iran/2019-12-04/irans-protests-are-not-just-aboutgas-prices. Last accessed: 17 apr. 2020.

KARL, Terry Lynn. The perils of the petro-state: reflections on the paradox of plenty. Journal of International Affairs, p. 31-48, 1999.

LEÓN, José María; KURMANAEV, Anatoly. Ecuador Gives Glimpse Into Pandemic's Impact on Latin America. The New York Times, [s.I.], 14 apr. 2020. Available in:

https://www.nytimes.com/2020/04/08/world/americas/ecuador-coronavirus.html. Last accessed: 23 apr. 2020.

LEVITSKY, Steven; ROBERTS, Kenneth M. (Ed.). The resurgence of the Latin American left. Baltimore: JHU Press, 2011. P. 1-28

LEWIS, W. Arthur. The Theory of Economic Growth. London: George Allen \& Unwin, 1955.

LONG, Gideon. Ecuador ends fuel subsidies to keep \$4.2bn IMF programme on track.

Financial Times, [s.l.], 2 oct. 2019. Available in: https://www.ft.com/content/6gbedocee52b-11eg-9743-db5a370481bc. Last accessed: 05 mar. 2020.

MAIDENBERG, H. J. Oil Companies Find Ecuador's Long-Sought Eldorado. The New York Times, 18 july. 1971. Available in: https://www.nytimes.com/1971/07/18/archives/oilcompanies-find-ecuadors-longsought-eldorado-tuna-fish-however.html. Last accessed: 12 mar.2020.

MATTHES, Sebastian. Der Neo-Extraktivismus und Die Bürgerrevolution.

Rohstoffwirtschaft und soziale Ungleichheiten in Ecuador. Springer Fachmedien Wiesbaden, 2019.

MAYER, Jörg. 1999. Introduction. In: MAYER, Jörg; CHAMBERS, Brian; FAROOQ, Ayisha (Ed.). Development Policies in Natural Resource Economies. Cheltenham: Edward Elgar Publishing, 1999.

MENALDO, Víctor. The Institutions Curse: Natural Resources, Politics, and Development. Cambridge: Cambridge University Press, 2016. 
MOMMER, Bernard. Global Oil and the Nation State. New York: Oxford University Press, 2002.

MONTENEGRO, Javier. La nómina continúa obesa. El Expreso, [s.I.], 20 sept. 2019. Available in: https://www.expreso.ec/actualidad/nomina-empresas-publicas-estadoempleados-KI3138491. Last accessed: 20 mar. 2020.

OLEAS MONTALVO, Julio. Ecuador 1972-1999: del desarrollismo petrolero al ajuste neoliberal. PhD diss., Universidad Andina Simón Bolívar sede Ecuador, [Quito?], 2013.

OROZCO, Mónica. "Ecuador vendió incluso el petróleo que no tenía en 2016." El Comercio, [s.I.], 14 feb. 2018. Available in: https://www.elcomercio.com/actualidad/ecuador-ventapetroleo-petrotailandia-petroecuador.html. Last accessed: 12 mar. 2020.

OSPINA PERALTA, Pablo. Estamos haciendo mejor las cosas con el mismo modelo antes que cambiarlo: La revolución ciudadana en Ecuador (2007-2012). In: LANDO, Edgardo; ARZE, Carlos; GÓMEZ, Javier; OSPINA PERALTA, Pablo; ÁLVAREZ, Víctor. Promesas en su laberinto: cambios y continuidades en los gobiernos progresistas de América Latina. La Paz: IEE; CEDLA; CIM, 2013. p. 177-278.

OVADIA, Jesse Salah. The Petro-Developmental State in Africa: Making Oil Work in Angola, Nigeria and the Gulf of Guinea. London: Hurst, 2016.

PACHECO, Mayra. 2019. 10 avatares del fallido proyecto de la Refinería del Pacífico. El Comercio, [s.l.], 28 aug. 2019. Available in:

https://www.elcomercio.com/actualidad/ecuador-petroleo-refineria-pacifico-

financiamiento.html. Last accessed: 29 mar. 2020.

PETERS, Stefan. "Beyond Curse and Blessing: Rentier Society in Venezuela." In: ENGELS, Bettina; DIETZ, Kristina (edit). Contested Extractivism, Society and the State: Struggles over Mining and Land. London: Palgrave Macmillan UK, 2017. p.45-68.

PETERS, Stefan. I can't live with or without you: Los desafíos de la transformación ambiental para las sociedades dependientes del petróleo. Identidades, [s.I.], v.10, n. 19, p.41-58, oct. 2020.

PETERS, Stefan. Post-crecimiento y buen vivir: discursos políticos alternativos o alternativas políticas? In: ENDARA, Gustavo (coord.). Post-crecimiento y buen vivir. Propuestas globales para la construcción de sociedades equitativas y sustentables. Quito: FES-ILDIS, 2014. p. 123-161.

PETERS, Stefan. Rentengesellschaften. Der lateinamerikanische (Neo) Extraktivismus im transregionalen Vergleich. Baden-Baden: Nomos Verlag, 2019.

PONCE, Karina; VÁSOUEZ, Andrés; VIVANCO, Pablo; MUNCK, Ronaldo. The October 2019 Indigenous and Citizens 'Uprising in Ecuador. Latin American Perspectives, [S.I.], v. 47, n. 5, p. 9-19, 2020. 
PURCELL, Thomas F.; FERNANDEZ, Nora; MARTINEZ, Estefania. Rents, knowledge and neo-structuralism: transforming the productive matrix in Ecuador. Third World Quarterly, [s. I.], v. 38, n. 4, p. 918-938, 2017.

PURCELL, Thomas F.; FERNÁNDEZ, Nora; MARTINEZ, Estefania; POVEDA, Verónica. Ecuador: The Change of the Productive Matrix and the Challenge of Import Substitution. d+i Llorente y Cuenca, Ecuador, [s. I.], v. 2, p. 14, 2014.

PURROY, M. Ignacio. Sesenta años en busca de la diversificación. Revista SIC, [s. I.], v. 6o, n. 600, 1997.

REUTERS. Ecuador declares state of emergency as protesters decry end to fuel subsidies. The Guardian, 3 Oct. 2019. Available in: https://www.theguardian.com/world/2019/oct/o3/ecuador-state-of-emergency-fuelsubsidies-protest. Last accessed: 05 mar. 2020.

ROBINSON, James A.; TORVIK, Ragnar. White elephants. Journal of public economics, [s. I.], v. 89, n. 2-3, p. 197-210, 2005.

ROSS, Michael L. Does oil hinder democracy? World politics, v. 53, n. 3, p. 325-361, 2001.

ROSS, Michael L. The oil curse: How petroleum wealth shapes the development of nations. Princeton University Press, 2013.

ROSTOW, Walt Whitman. The stages of economic growth: A non-communist manifesto. Cambridge university press, 1960.

SAAD-FILHO, Alfredo; WEEKS, John. Curses, diseases and other resource confusions. Third World Quarterly, v. 34, n. 1, p. 1-21, 2013.

SACHS, Jeffrey D.; WARNER, Andrew M. Natural resource abundance and economic growth. National Bureau of Economic Research, 1995. Working Paper 5398.

SALAS, Miguel Tinker. The enduring legacy: Oil, culture, and society in Venezuela. Durham: Duke University Press, 2009.

STUTZMAN, Ronald. El mestizaje: an all-inclusive ideology of exclusion. STUTZMAN, Ronald; WHITTEN, Norman E. Cultural Transformations and Ethnicity in Modern Ecuador. Urbana: University of Illinois Press. 1981. p. 45-94.

TIBÁN, Lourdes. Tatay Correa: Cronología de la persecución y criminalización durante el correísmo. Ecuador 2007-2017. Quito: CACS, 2018.

UNCTAD (United Nations Conference on Trade and Development). Commodity Dependence: A Twenty-Year Perspective. Geneva: UNCTAD, 2019.

UNCTAD (United Nations Conference on Trade and Development). Trade and Development Report 2016: Structural Transformation for Inclusive and Sustained Growth. Geneva: UNCTAD, 2016. 
USLAR PIETRI, Arturo. Sembrar el petróleo. Ahora, [s.I.], 14 july 1936.

VALENCIA, Alexandra. 2015. UPDATE 1-Ecuador signs $\$ 2.5$ bln oil supply deal with Thailand. Reuters, [s.I.], 31 july 2015. Available in: https://www.reuters.com/article/ecuadorpetroecuador/update-1-ecuador-signs-2-5-bln-oil-supply-deal-with-thailandidUSL1N10B2TA20150731. Last accessed: 12 mar. 2020.

VALENCIA, Alexandra. Ecuador seeks renegotiation of China oil sales, loans. Reuters, [s.I.], 24 oct. 2017. Available in: https://www.reuters.com/article/ecuador-oil/ecuador-seeksrenegotiation-of-china-oil-sales-loans-idUSL2 $\mathrm{N}_{1} \mathrm{MZ}_{1} \mathrm{G}_{5}$. Last accessed: 12 mar. 2020.

WAINER, Andrés; BELLONI, Paula. ¿Hacia dónde va América Latina? El desarrollo desigual en la periferia globalizada. Cuadernos de Economía, [s.I.], v. 35, n. 69, p. 555-581, 2016.

WILCOCK, Neil; SCHOLZ, Corina; EISENHANS, Hartmut. Hartmut Elsenhans and a Critique of Capitalism: Conversations on Theory and Policy Implications. Basingstoke: Palgrave Macmillan, 2016.

WORLD BANK. Ecuador: problemas y perspectivas de desarrollo. Washington D.C.: World Bank, 1980.

WTO (WORLD TRADE ORGANIZATION). World Trade Report 2014. Trade and Development: Recent Trends and the Role of the WTO. Geneva: WTO, 2014.

\section{Author details}

Pedro Alarcón

Facultad Latinoamericana de Ciencias Sociales (FLACSO), Quito, Pichincha, Ecuador.

E-mail: pedroalarcon76@gmail.com

ORCID iD: https://orcid.org/0000-0001-7182-1496

\section{Stefan Peters}

Diretor Acadêmico do Instituto Alemão-Colombiano da Paz - CAPAZ e Cátedra de Estudos para a Paz da Justus Liebig University Giessen (Alemanha). Estudou Ciência Política na Philipps-University Marburg e na Universidad Complutense de Madrid e obteve seu PhD em Ciência Política na University of Kassel (Alemanha). Stefan Peters trabalha nas áreas de Neoextrativismo e Rentismo, Desigualdades Sociais, Educação, Estudos da Memória, Teoria do Desenvolvimento e Relações Norte Sul. Foi professor visitante e pesquisador em universidades de países como Cuba, Argentina, Equador e Porto Rico. E-mail: stefan.peters@instituto-capaz.org 